\title{
Bacillus isabeliae sp. nov., a halophilic bacterium isolated from a sea salt evaporation pond
}

\author{
Luciana Albuquerque, ${ }^{1}$ Igor Tiago, ${ }^{1}$ Marco Taborda, ${ }^{1}$ M. Fernanda Nobre, ${ }^{1}$ \\ António Veríssimo ${ }^{1}$ and Milton S. da Costa ${ }^{2}$
}

Correspondence

Milton S. da Costa

milton@ci.uc.pt

\author{
${ }^{1}$ Centro de Neurociências e Biologia Celular, Department of Zoology, University of Coimbra, \\ 3004-517 Coimbra, Portugal \\ ${ }^{2}$ Department of Biochemistry, University of Coimbra, 3001-401 Coimbra, Portugal
}

Species of the genus Bacillus have been isolated from a large variety of aquatic and terrestrial environments, demonstrating their ubiquity. Among these, moderately halophilic Bacillus species have been isolated from salterns, estuarine water, salt lakes, salty foods, sea ice and seawater (Agnew et al., 1995; Arahal et al., 1999; Nielsen et al., 1994; Ventosa et al., 1989; Yoon et al., 2004). During a survey of the bacterial diversity of a sea salt evaporation pond on the Island of Sal in the Cape Verde Archipelago, several halophilic, Gram-positive bacteria were isolated and characterized. One of the isolates, designated strain CVS$8^{\mathrm{T}}$, was found to be phylogenetically related to species of the genus Bacillus, sharing several physiological and biochemical characteristics with the strains belonging to the species Bacillus acidicola (Albert et al., 2005) and Bacillus shackletonii (Logan et al., 2004). Nevertheless, this novel organism had distinctly higher $\mathrm{NaCl}$ and $\mathrm{pH}$ requirements for optimal growth as well as a distinctive

The GenBank/EMBL/DDBJ accession number for the $16 \mathrm{~S}$ rRNA gene sequence of strain CVS-8 ${ }^{\top}$ is $\mathrm{AM} 503357$.

A maximum-parsimony phylogenetic dendrogram based on 16S rRNA gene sequences and a graph showing the effect of salt on growth of strain CVS- $8^{\top}$ are available as supplementary figures with the online version of this paper. fatty acid profile. Here, we report the morphological, physiological, chemotaxonomic and phylogenetic characterization of strain CVS- $8^{\mathrm{T}}$, which is proposed as representing a novel species of the genus Bacillus.

Strain CVS $-8^{\mathrm{T}}$ was isolated from a sea salt evaporation pond on the Island of Sal in the Cape Verde Archipelago (República de Cabo Verde), using solid R3A-V medium (Tiago et al., 2006) at pH 7.0 and containing $2 \%(\mathrm{w} / \mathrm{v})$ $\mathrm{NaCl}$. Soil samples $(3 \mathrm{~g})$ were resuspended in sterile blenders with sterile solution of $2 \%(\mathrm{w} / \mathrm{v}) \mathrm{NaCl}$. Single drops of the homogenate were spread on $\mathrm{R} 3 \mathrm{~A}-\mathrm{V}$ agar plates. These preparations were incubated at $37{ }^{\circ} \mathrm{C}$ for up 5 days. Despite repeated attempts to isolate additional strains, only one isolate was obtained. Cultures were purified by means of subculturing on the same medium and were maintained at $-70{ }^{\circ} \mathrm{C}$ in Degryse medium 162 containing $3 \%(\mathrm{w} / \mathrm{v}) \mathrm{NaCl}$ and $15 \%(\mathrm{w} / \mathrm{v})$ glycerol (Degryse et al., 1978). The organism was routinely cultured in Degryse medium 162 containing $5 \%(\mathrm{w} / \mathrm{v}) \mathrm{NaCl}$ at $37{ }^{\circ} \mathrm{C}$ for up 5 days, unless otherwise stated (Albuquerque et al., 2005). The type strains of Bacillus acidicola (DSM $14745^{\mathrm{T}}$ ) and B. shackletonii (LMG $18435^{\mathrm{T}}$ ) were used for comparative purposes.

The temperature range for growth of strain CVS $-8^{\mathrm{T}}$ was tested in liquid medium in a reciprocal water-bath shaker 
between 15 and $45{ }^{\circ} \mathrm{C}$; the $\mathrm{pH}$ range for growth, from pH 5.5 to $\mathrm{pH} 10.5$, was determined at $37{ }^{\circ} \mathrm{C}$ in the same medium buffered using $20 \mathrm{mM}$ MES, TRIS and CAPSO. The $\mathrm{NaCl}$ range for growth was determined in liquid medium without additional $\mathrm{NaCl}$ and at $\mathrm{NaCl}$ concentrations of up to $16.0 \%(\mathrm{w} / \mathrm{v})$. Enzymic activities were determined using the API ZYM system (bioMérieux). Anaerobic growth was assessed on solidified Degryse medium with $5.0 \%(\mathrm{w} / \mathrm{v}) \mathrm{NaCl}$ and $\mathrm{KNO}_{3}\left(1.0 \mathrm{~g} \mathrm{l}^{-1}\right)$ in anaerobic chambers (GENbox anaer; bioMérieux). Tests to determine the assimilation of single carbon sources were performed in a defined medium composed of Degryse basal salts containing $5.0 \%(\mathrm{w} / \mathrm{v}) \mathrm{NaCl}$, yeast extract $\left(0.1 \mathrm{~g} \mathrm{l}^{-1}\right)$, ammonium sulfate $\left(0.5 \mathrm{~g} \mathrm{l}^{-1}\right)$, single carbon sources $\left(2.0 \mathrm{~g} \mathrm{l}^{-1}\right)$ and $2 \%(\mathrm{w} / \mathrm{v})$ deionized water-washed agar (Oxoid). Plate cultures ( $48 \mathrm{~h}$ ) were resuspended in the basal salts medium (turbidity equivalent to a McFarland no. 1 standard) and single drops of the suspension were placed on Petri dishes, each of which contained a single carbon source; the plates were examined visually for up to 5 days. Acid production from carbohydrates was determined with the API $50 \mathrm{CH}$ system (bioMérieux) according to the manufacturer's instructions, using API $50 \mathrm{CHB} / \mathrm{E}$ medium (bioMérieux) containing $5.0 \% \quad(\mathrm{w} / \mathrm{v}) \quad \mathrm{NaCl}$. Results were recorded after $24 \mathrm{~h}, 48 \mathrm{~h}$ and 5 days incubation at $37^{\circ} \mathrm{C}$.

Peptidoglycan analysis was performed by using the method of Schleifer \& Kandler (1972) and Schleifer (1985); analysis of respiratory quinones was performed according Tindall (1989). Cultures for fatty acid analyses were grown on solidified Degryse medium 162 containing $5 \%(\mathrm{w} / \mathrm{v}) \mathrm{NaCl}$ buffered at $\mathrm{pH} 7.5$, incubated in sealed plastic bags submerged in a water bath at $37{ }^{\circ} \mathrm{C}$ for $48 \mathrm{~h}$. For comparison, fatty acid analyses were also performed on the type strains of $B$. acidicola and B. shackletonii grown on Degryse medium 162 buffered at $\mathrm{pH} 6.2$ (B. acidicola) or pH 6.5 (B. shackletonii) with incubation in sealed plastic bags submerged in a water bath at $37{ }^{\circ} \mathrm{C}$ for $24 \mathrm{~h}$. Salt was not added to the culture media used to grow $B$. acidicola and $B$. shackletonii because these organisms show optimum growth in media without added $\mathrm{NaCl}$. Fatty acid methyl esters were extracted as described previously (Moreira et al., 2000); their identification and quantification, as well as the numerical analysis of the fatty acid profiles, were performed by using the standard MIS Library Generation Software (Microbial ID). Polar lipid analyses were performed as described previously (Prado et al., 1988).

The $\mathrm{G}+\mathrm{C}$ content of the DNA was determined by HPLC as described by Mesbah et al. (1989). The $16 \mathrm{~S}$ rRNA gene was amplified with a PCR and sequenced as described by Rainey et al. (1996). Phylogenetic analyses were performed using the ARB software package (Ludwig et al., 2004). A phylogenetic tree was constructed using the neighbourjoining (Saitou \& Nei, 1987) algorithm. Tree topologies were evaluated by performing a bootstrap analysis (Felsenstein, 1985) of 1000 resamplings of the dataset.

Comparative analyses of 1481 nucleotide positions of the 16S rRNA gene sequence of strain CVS- $8^{\mathrm{T}}$ with those of other lineages within the low- $\mathrm{G}+\mathrm{C}$, Gram-positive bacteria showed that the novel isolate belonged to the genus Bacillus (Fig. 1). The highest levels of pairwise $16 \mathrm{~S}$ rRNA gene sequence similarity were found with respect to the type strains of B. shackletonii (97.5\%) and B. acidicola $(97.3 \%)$. Despite these similarity values, the phylogenetic tree, irrespective of the method used for construction,

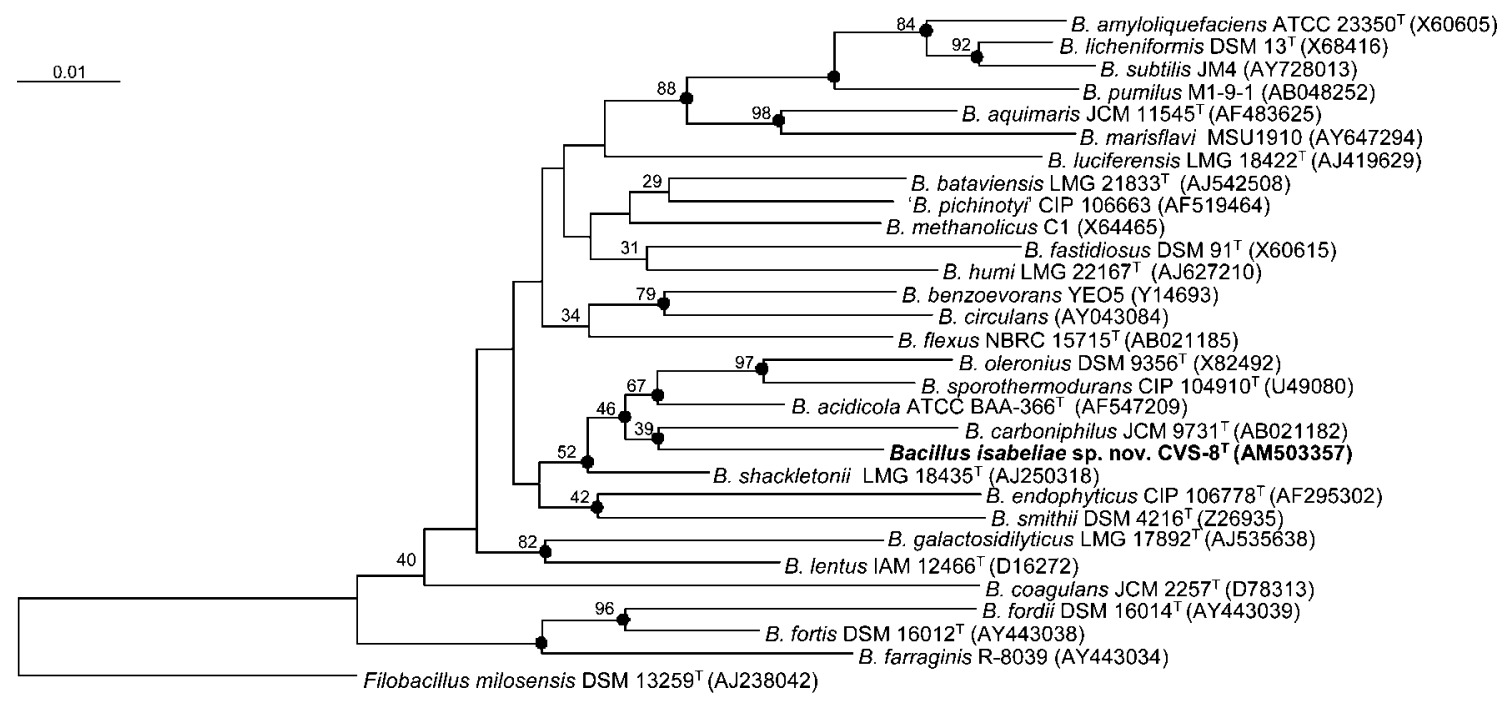

Fig. 1. Neighbour-joining phylogenetic dendrogram based on a comparison of the 16S rRNA gene sequences of strain CVS$8^{\top}$ and the closest phylogenetic relatives. Numbers on the tree indicate bootstrap support (\%), derived from 1000 replications. Bar, 1 inferred nucleotide substitutions per 100 nucleotides. Filled circles indicate branching topologies that are also present in the tree obtained using the maximum-parsimony method (see Supplementary Fig. S1 in IJSEM Online). 
showed a peculiar topology whereby strain CVS $-8^{\mathrm{T}}$ formed a branch with the type strain of Bacillus carboniphilus (Fujita et al., 1996). However, the 16S rRNA gene sequence similarity between strain CVS- $8^{\mathrm{T}}$ and that of the type strain of $B$. carboniphilus was only $96.4 \%$. Furthermore, the topology for the branch with B. carboniphilus and CVS- $8^{\mathrm{T}}$ showed poor bootstrap support (Fig. 1). Regrettably, the type strain of $B$. carboniphilus is not freely available for study, as discussed by the Subcommittee on the taxonomy of the Genus Bacillus and related organisms (Logan, 2005), and the description of the species (Fujita et al., 1996) is based on a small number of characteristics, making it difficult to compare the phenotypic characteristics of this organism with those of strain CVS- $8^{\mathrm{T}}$. Therefore we considered it appropriate to compare the phenotypic characteristics of strain CVS $-8^{\mathrm{T}}$ with the type strains of B. shackletonii and B. acidicola. The $\mathrm{G}+\mathrm{C}$ content of the DNA of strain CVS $-8^{\mathrm{T}}$ was $37.9 \mathrm{~mol} \%$.

Strain CVS- $8^{\mathrm{T}}$ formed orange-pigmented colonies, the cells stained Gram-positive and were curved rods (Fig. 2). Endospores (positioned subterminally in swollen sporangia) were rarely observed, but their existence was confirmed in cells from a few colonies that formed after the incubation of cultures at 60 and $70{ }^{\circ} \mathrm{C}$ for 20 and $10 \mathrm{~min}$, respectively. The isolate had an optimum growth temperature between 35 and $37{ }^{\circ} \mathrm{C}$ and did not grow at 15 or $45^{\circ} \mathrm{C}$. The optimum pH of the novel organism was between 7.5 and 8.0. Optimum growth occurred at $\mathrm{NaCl}$ concentrations between 4 and $6 \%$ $(\mathrm{w} / \mathrm{v})$ and no growth occurred in medium without $\mathrm{NaCl}$ or in medium containing $16 \%(\mathrm{w} / \mathrm{v}) \mathrm{NaCl}$ (see Supplementary Fig. S2, available with the online version of this paper). On the other hand, the type strains of $B$. acidicola and $B$. shackletonii grew in medium without salt, showed a narrow range of salt tolerance and had a lower optimum $\mathrm{pH}$ for growth (Table 1).

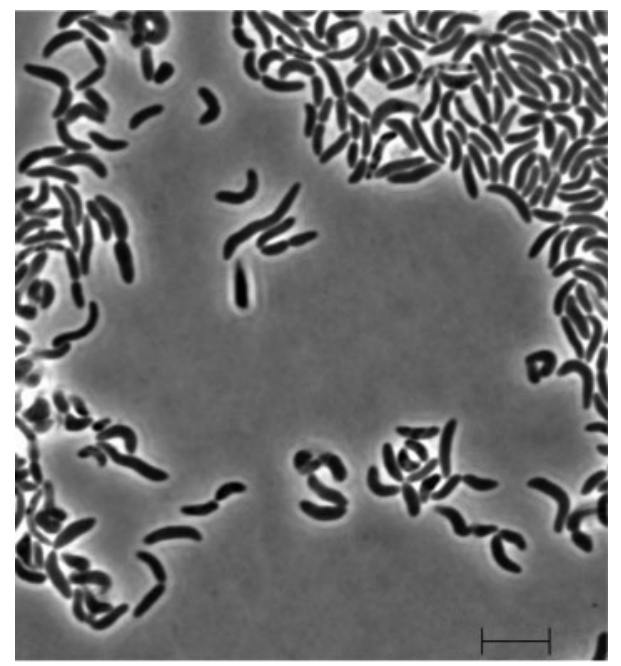

Fig. 2. Phase-contrast micrograph of cells of strain CVS-8 ${ }^{\top}$ cultivated for $24 \mathrm{~h}$. Bar, $5 \mu \mathrm{m}$.
The novel isolate was oxidase- and catalase-positive. Other enzyme activities are listed in the species description. Yeast extract was required for growth on single carbon sources. Strain CVS- $8^{\mathrm{T}}$ assimilated carbohydrates and organic acids. Of the amino acids tested, proline was the only one that was assimilated. Acid was produced from several carbohydrates. Nitrate was not reduced to nitrite and anaerobic growth in the presence of nitrate was not observed.

Like the great majority of endospore-forming bacteria, strain CVS $-8^{\mathrm{T}}$ possessed a cell-wall peptidoglycan structure of type Al $\gamma$ with meso-diaminopimelic acid as the diagnostic diamino acid. Diphosphatidylglycerol, phosphatidylethanolamine, phosphatidylglycerol and an unknown aminoglycophospholipid were identified by using TLC. The major respiratory lipoquinone was MK-7. The major fatty acids of strain CVS- $8^{\mathrm{T}}$ were iso-15:0 $(24.8 \%), 16: 0$ $(17.5 \%)$, anteiso-15:0 (15.6\%) and iso-16:0 (11.6\%) (Table 2). However, strain CVS- $8^{\mathrm{T}}$ and the type strains of $B$. acidicola and B. shackletonii could be clearly distinguished from each other from the relative amounts of these fatty acids. Furthermore, strain CVS- $8^{\mathrm{T}}$ possessed

Table 1. Differentiating characteristics of strain CVS-8 $8^{\top}$ and the type strains of $B$. acidicola and $B$. shackletonii

Taxa: 1 , strain CVS- $8^{\mathrm{T}} ; 2$, B. acidicola DSM $14745^{\mathrm{T}} ; 3$, B. shackletonii LMG $18435^{\mathrm{T}}$. All data are from this study unless indicated otherwise. + , Positive; - , negative; $(+)$, weakly positive.

\begin{tabular}{|lccc|}
\hline Characteristic & $\mathbf{1}$ & $\mathbf{2}$ & $\mathbf{3}$ \\
\hline Cell motility & - & + & + \\
Colony pigmentation & Orange & Cream & Cream \\
NaCl requirement for growth & + & - & - \\
NaCl range $(\%)$ & $1-14$ & $0-2$ & $0-3$ \\
NaCl optimum $(\%)$ & $4-6$ & 0 & 0 \\
Growth temperature $\left({ }^{\circ} \mathrm{C}\right)$ range & $20-40$ & $20-42.5$ & $20-52.5$ \\
Optimum temperature $\left({ }^{\circ} \mathrm{C}\right)$ & $35-37$ & $35-37$ & $42.5-50$ \\
pH range & $6.5-8.5$ & $3.5-7.0$ & $4.5-8.5$ \\
Optimum pH & $7.5-8.0$ & $5.0-6.5$ & $5.5-7.0$ \\
Oxidase & + & - & + \\
Starch hydrolysis & + & + & - \\
Acid production from: & & & \\
Glycerol & - & + & - \\
D-Ribose & $(+)$ & + & $(+)$ \\
D-Xylose & $(+)$ & + & - \\
D-Galactose & - & + & $(+)$ \\
D-Glucose & - & + & + \\
D-Fructose & $(+)$ & + & $(+)$ \\
D-Mannose & - & + & $(+)$ \\
L-Sorbose & $(+)$ & - & - \\
D-Mannitol & - & + & $(+)$ \\
Maltose & - & + & $(+)$ \\
D-Lactose & - & + & $(+)$ \\
Sucrose & & + & - \\
DNA G+C content $($ mol\%) & 37.9 & $43.2^{*}$ & $35.4-36.8 \dagger$ \\
& & & \\
\hline
\end{tabular}

${ }^{\star}$ Data from Albert et al. (2005).

$\dagger$ Data from Logan et al. (2004). 
Table 2. Fatty acid contents (\%) of strain CVS- $8^{\top}$ and the type strains of $B$. acidicola and $B$. shackletonii

Strains: 1 , CVS-8 ${ }^{\mathrm{T}} ; 2$, B. acidicola DSM $14745^{\mathrm{T}} ; 3$, B. shackletonii $\mathrm{LMG}$ $18435^{\mathrm{T}}$. Values from this study are given as means $\pm \mathrm{SD}$ (three replicates). -, Not detected; $\operatorname{tr}$, trace $(<0.5 \%)$.

\begin{tabular}{|lccc|}
\hline Fatty acid & $\mathbf{1}$ & $\mathbf{2}$ & $\mathbf{3}$ \\
\hline iso-13:0 & $1.0 \pm 0.1$ & $\operatorname{tr}$ & - \\
iso $14: 0$ & $6.9 \pm 0.3$ & $0.6 \pm 0$ & $0.5 \pm 0$ \\
$14: 0$ & $4.2 \pm 0$ & $1.2 \pm 0.1$ & $0.5 \pm 0$ \\
iso- $15: 0$ & $24.8 \pm 0.1$ & $58.4 \pm 0.2$ & $29.6 \pm 0.1$ \\
anteiso-15:0 & $15.6 \pm 0.4$ & $19.4 \pm 0.1$ & $22.2 \pm 0.4$ \\
$15: 0$ & $3.1 \pm 0.2$ & - & $\operatorname{tr}$ \\
$16: 1 \omega 7 c$ alcohol & $1.8 \pm 0.1$ & - & - \\
iso-16:0 & $11.6 \pm 0$ & $1.2 \pm 0$ & $6.4 \pm 0.3$ \\
$16: 1 \omega 11 c$ & $2.0 \pm 0$ & - & - \\
Summed feature $3^{*}$ & $2.7 \pm 0$ & - & - \\
$16: 0$ & $17.5 \pm 0.2$ & $2.6 \pm 0.1$ & $1.9 \pm 0.1$ \\
iso- $17: 0$ & $2.1 \pm 0.1$ & $6.3 \pm 0$ & $3.1 \pm 0.1$ \\
anteiso- $17: 0$ & $4.1 \pm 0.1$ & $10.0 \pm 0.1$ & $33.7 \pm 0.6$ \\
\hline
\end{tabular}

${ }^{\star}$ Summed features represent groups of two or three fatty acids that could not be separated by GLC with the MIDI system. Summed feature 3 contained one or more of the following fatty acids: $16: 1 \omega 7 \mathrm{cl}$ $16: 1 \omega 6 c /$ iso- $15: 02-\mathrm{OH}$.

straight-chain $15: 0$ as well as $16: 1 \omega 7 c$ alcohol, $16: 1 \omega 11 c$ and summed feature $3(16: 1 \omega 7 c / 16: 1 \omega 6 c /$ iso-15:0 2-OH), which were not detected in the type strains of $B$. acidicola and B. shackletonii.

Despite similar characteristics and close phylogenetic relatedness, strain CVS $-8^{\mathrm{T}}$ can be clearly distinguished from the type strains of $B$. acidicola and B. shackletonii, i.e. from the $\mathrm{NaCl}$ requirement for growth, the $\mathrm{pH}$ range, the fatty acid composition and other phenotypic traits. On the basis of these findings, strain CVS $-8^{\mathrm{T}}$ represents a novel species of the genus Bacillus, for which the name Bacillus isabeliae sp. nov. is proposed.

\section{Description of Bacillus isabeliae sp. nov.}

Bacillus isabeliae (i.sa.be.li'ae. N.L. gen. fem. n. isabeliae of Isabel, in honour of Portuguese microbiologist Isabel Spencer-Martins).

Cells are curved rods that are $0.5-1.0 \mu \mathrm{m}$ in width and $2.8-$ $5.7 \mu \mathrm{m}$ in length. Gram stain is positive. Cells are nonmotile and form rarely observed endospores in subterminal swollen sporangia. Colonies on Degryse 162 medium containing $5 \%(\mathrm{w} / \mathrm{v}) \mathrm{NaCl}$ are orange. Strictly aerobic and heterotrophic. Oxidase- and catalase-positive. Optimum growth temperature is approximately 35$37{ }^{\circ} \mathrm{C}$; growth does not occur at 15 or $45^{\circ} \mathrm{C}$. Optimum $\mathrm{pH}$ is between 7.5 and 8.0; growth does not occur at $\mathrm{pH} 6.0$ or $\mathrm{pH}$ 9.0. Optimum growth occurs at $\mathrm{NaCl}$ concentrations between 4 and $6 \%(\mathrm{w} / \mathrm{v})$; no growth occurs in medium without $\mathrm{NaCl}$ or in medium containing $16 \%$ (w/v) $\mathrm{NaCl}$. Cell-wall peptidoglycan is of the $\mathrm{A} 1 \gamma$ type with meso-diaminopimelic acid as the diagnostic diamino acid. The major respiratory quinone is MK-7. Predominant fatty acids are iso-15:0, 16:0, anteiso-15:0 and iso-16:0; smaller amounts of iso-13:0, iso-14:0, 14:0, 15:0, $16: 1 \omega 7 c$ alcohol, $16: 1 \omega 11 c$, summed feature 3 , iso-17:0 and anteiso-17:0 are also present. The major polar lipids are diphosphatidylglycerol, phosphatidylethanolamine, phosphatidylglycerol and an unknown aminoglycophospholipid. Yeast extract or growth factors are required for growth. Nitrate is not reduced. Aesculin, arbutin, starch and xylan are hydrolysed, but gelatin, casein, elastin, hippurate and Tweens 20 to 80 are not hydrolysed. Positive for DNase, esterase lipase (C8), leucine arylamidase, valine arylamidase and $\alpha$-chymotrypsin. Negative for alkaline phosphatase, esterase (C4), lipase (C14), cystine arylamidase, trypsin, acid phosphatase, naphthol-AS-BI-phosphohydrolase, $\alpha$-galactosidase, $\beta$-glucosidase, $\beta$-galactosidase, $\alpha$ galactosidase, $N$-acetyl- $\beta$-glucosaminidase, $\alpha$-mannosidase and $\alpha$-fucosidase. Glucose, fructose, xylose, sucrose, maltose, trehalose, cellobiose, succinate, $\alpha$-ketoglutarate, lactate, malate, pyruvate, citrate, acetate and proline are assimilated. Mannose, galactose, sorbose, D-arabinose, Larabinose, ribose, lactose, melezitose, melibiose, L-rhamnose, raffinose, fucose, ribitol, xylitol, sorbitol, erythritol, arabitol, mannitol, myo-inositol, glycerol, aspartate, glutamate, alanine, asparagine, cysteine, phenylalanine, glycine, histidine, isoleucine, lysine, methionine, glutamine, arginine, serine, threonine, valine and ornithine are not assimilated. Acid is produced from ribose, xylose, fructose, sorbose, cellobiose, sucrose, trehalose, melezitose, glycogen, gentiobiose, turanose, tagatose and potassium 5-ketogluconate. Acid is not produced from glycerol, erythritol, arabinose, L-xylose, ribitol, methyl $\beta$ $\mathrm{D}$-xylopyranoside, galactose, glucose, mannose, rhamnose, galactitol, inositol, mannitol, sorbitol, methyl $\alpha$-D-mannopyranoside, methyl $\alpha$-D-glucopyranoside, $N$-acetylglucosamine, amygdalin, arbutin, salicin, maltose, lactose, melibiose, inulin, raffinose, starch, xylitol, lyxose, Dfucose, L-fucose, D-arabitol, L-arabitol, gluconate or 2ketogluconate. The DNA $\mathrm{G}+\mathrm{C}$ content is $37.9 \mathrm{~mol} \%$ (HPLC method).

The type strain, strain $\mathrm{CVS}-8^{\mathrm{T}}$ (=LMG $22838^{\mathrm{T}}=\mathrm{CIP}$ $108578^{\mathrm{T}}$ ), was isolated from a sea salt evaporation pond on the Island of Sal in the Cape Verde Archipelago.

\section{Acknowledgements}

The research was funded, in part, by the Fundação para a Ciência e a Tecnologia (POCI/BIA-BDE/60704/2004). We would also like to thank José Tiago, for collecting the samples, and Hans G. Trüper (University of Bonn, Germany) for the etymology of the species epithet.

\section{References}

Agnew, M. D., Koval, S. F. \& Jarrell, K. F. (1995). Isolation and characterization of novel alkaliphiles from bauxite-processing waste 
and description of Bacillus vedderi sp. nov., a new obligate alkaliphile. Syst Appl Microbiol 18, 221-230.

Albert, R. A., Archambault, J., Rosselló-Mora, R., Tindall, B. J. \& Matheny, M. (2005). Bacillus acidicola sp. nov., a novel mesophilic, acidophilic species isolated from acidic Sphagnum peat bogs in Wisconsin. Int J Syst Evol Microbiol 55, 2125-2130.

Albuquerque, L., Simões, C., Nobre, M. F., Pino, N. M., Battista, J. R., Silva, M. T., Rainey, F. A. \& da Costa, M. S. (2005). Truepera radiovictrix gen. nov., sp. nov., a new radiation resistant species and the proposal of Trueperaceae fam. nov. FEMS Microbiol Lett 247, 161-169.

Arahal, D. R., Marquez, M. C., Volcani, B. E., Schleifer, K.-H. \& Ventosa, A. (1999). Bacillus marismortui sp. nov., a new moderately halophilic species from the Dead Sea. Int J Syst Bacteriol 49, 521-530.

Degryse, E., Glansdorff, N. \& Pierard, A. (1978). A comparative analysis of extreme thermophilic bacteria belonging to the genus Thermus. Arch Microbiol 117, 189-196.

Felsenstein, J. (1985). Confidence limits on phylogenies: an approach using the bootstrap. Evolution 39, 783-791.

Fujita, T., Shida, O., Takagi, H., Kunugita, K., Pankrushina, A. N. \& Matsuhashi, M. (1996). Description of Bacillus carboniphilus sp. nov. Int J Syst Bacteriol 46, 116-118.

Logan, N. A. (2005). International Committee on Systematics of Prokaryotes; Subcommittee on the taxonomy of the genus Bacillus and related organisms: Minutes of the meeting, 30 July 2002, Paris, France. Int J Syst Evol Microbiol 55, 977-979.

Logan, N. A., Lebbe, L., Verhelst, A., Goris, J., Forsyth, G., RodriguezDiaz, M., Heyndrickx, M. \& De Vos, P. (2004). Bacillus shackletonii sp. nov., from volcanic soil on Candlemas Island, South Sandwich archipelago. Int J Syst Evol Microbiol 54, 373-376.

Ludwig, W., Strunk, O., Westram, R., Richter, L., Meier, H., Yadhukumar, Buchner, A., Lai, T., Steppi, S. \& other authors (2004). ARB: a software environment for sequence data. Nucleic Acids Res 32, 1363-1371.

Mesbah, M., Premachandran, U. \& Whitman, W. B. (1989). Precise measurement of the $\mathrm{G}+\mathrm{C}$ content of deoxyribonucleic acid by high-performance liquid chromatography. Int J Syst Bacteriol 39, 159-167.
Moreira, C., Rainey, F. A., Nobre, M. F., da Silva, M. T. \& da Costa, M. S. (2000). Tepidimonas ignava gen. nov., sp. nov., a new chemolithoheterotrophic and slightly thermophilic member of the $\beta$-Proteobacteria. Int J Syst Evol Microbiol 50, 735-742.

Nielsen, P., Rainey, F. A., Outtrup, H., Priest, F. G. \& Fritze, D. (1994). Comparative $16 \mathrm{~S}$ rDNA sequence analysis of some alkaliphilic bacilli and the establishment of a sixth rRNA group within the genus Bacillus. FEMS Microbiol Lett 117, 61-66.

Prado, A., da Costa, M. S. \& Madeira, V. M. C. (1988). Effect of growth temperature on the lipid composition of two strains of Thermus sp. J Gen Microbiol 134, 1653-1660.

Rainey, F. A., Ward-Rainey, N., Kroppenstedt, R. M. \& Stackebrandt, E. (1996). The genus Nocardiopsis represents a phylogenetically coherent taxon and a distinct actinomycete lineage: proposal of Nocardiopsaceae fam. nov. Int J Syst Bacteriol 46, 1088-1092.

Saitou, N. \& Nei, M. (1987). The neighbor-joining method: a new method for reconstructing phylogenetic trees. Mol Biol Evol 4, 406-425.

Schleifer, K. H. (1985). Analysis of the chemical composition and primary structure of murein. Methods Microbiol 18, 123-156.

Schleifer, K. H. \& Kandler, O. (1972). Peptidoglycan types of bacterial cell walls and their taxonomic implications. Bacteriol Rev 36, 407-477.

Tiago, I., Mendes, V., Pires, C., Morais, P. V. \& Veríssimo, A. (2006). Chimaereicella alkaliphila gen. nov., sp. nov., a Gram-negative alkaliphilic bacterium isolated from a nonsaline alkaline groundwater. Syst Appl Microbiol 29, 100-108.

Tindall, B. J. (1989). Fully saturated menaquinones in the archaebacterium Pyrobaculum islandicum. FEMS Microbiol Lett 60, 251-254.

Ventosa, A., Garcia, M. T., Kamekura, M., Onishi, H. \& RuizBerraquero, F. (1989). Bacillus halophilus sp. nov., a moderately halophilic Bacillus species. Syst Appl Microbiol 12, 162-165.

Yoon, J. H., Kim, I. G., Kang, K. H., Oh, T. K. \& Park, Y. H. (2004). Bacillus hwajinpoensis sp. nov. and an unnamed Bacillus genomospecies, novel members of Bacillus rRNA group 6 isolated from sea water of the East Sea and the Yellow Sea in Korea. Int J Syst Evol Microbiol 54, 803-808. 